Review

\title{
Natural Products as a Source of Anti-Inflammatory Agents Associated with Inflammatory Bowel Disease
}

\author{
Trishna Debnath, Da Hye Kim and Beong Ou Lim * \\ Department of Life Science, College of Biomedical \& Health Science, \\ Research Institute of Inflammatory Disease, Konkuk University, Chungju 380-701, Korea \\ * Author to whom correspondence should be addressed; E-Mail: beongou@kku.ac.kr; \\ Tel.: +82-43-840-3570; Fax: +82-43-856-3572.
}

Received: 27 April 2013; in revised form: 5 June 2013 / Accepted: 14 June 2013 /

Published: 19 June 2013

\begin{abstract}
Accumulating epidemiological and clinical study indicates that inflammation is a significant risk factor to develop various human diseases such as inflammatory bowel disease (IBD), chronic asthma, rheumatoid arthritis, multiple sclerosis, and psoriasis. Suppressing inflammation is therefore important to control or prevent various diseases. Among them, IBD is one of the major problems affecting people worldwide. IBD affects at least one in a thousand persons in many Western countries. Various natural products have been shown to safely suppress pro-inflammatory pathway and control IBD. In vivo and/or in vitro studies indicate that anti-IBD effects of natural products occur by inhibition of the expression of pro-inflammatory cytokines (for example, tumor necrosis factor- $\alpha$ (TNF- $\alpha$ ), intercellular adhesion molecule expression and pro-inflammatory mediators (such as inducible nitric oxide synthase (iNOS) and cyclooxygenase 2 (COX2), master transcription factors (such as nuclear factor- $\kappa \mathrm{B}(\mathrm{NF}-\kappa \mathrm{B})$ ), reactive oxygen species (ROS) and by improving the antioxidant activity. In this review, we summarize recent research focused on IBD and the effects that natural products have on IBD factors.
\end{abstract}

Keywords: natural products; inflammatory bowel disease; inflammation; cytokines; reactive oxygen species 


\section{Introduction}

Inflammation is the first biological response of the immune system to infection or irritation. The word 'inflammation' comes from the Latin “inflammo," meaning "I set alight, I ignite." A verity of stimuli such as physical damage, ultra violet irradiation, microbial invasion, and immune reactions are responsible for inflammation. Inflammation is characterized by redness, heat, swelling, and pain. Based on timing and pathological features, there are two major categories available for inflammation: acute and chronic. Chronic inflammatory disease is characterized by persistent inflammation. On the other hand, acute inflammation occurs over seconds, minutes, hours, and days.

IBD is inflammation within the gastrointestinal (GI) tract characterized by chronic or relapsing immune system activation. There are two types of IBD: ulcerative colitis and Crohn's disease [1]. Ulcerative colitis occurs in the inner lining of the colon (large intestine) or rectum and the common symptoms are diarrhea, abdominal cramps and rectal bleeding while those with Crohn's disease, experience pain in the abdomen, especially in the lower right side with symptoms - diarrhea, fatigue, weight loss and occasionally bleeding - and occurs in the deep layers of the intestinal wall.

Generally, anti-inflammatory drugs or immunosuppressive drugs such as 5-aminosalicylic acid (5-ASA) and 6-mercaptopurine are used to treat IBD; steroids and non-steroidal anti-inflammatory drugs are effective for temporary relief of symptoms. However, drug-induced severe side effects occur, and most of these treatments are inadequate. [2-4]. Therefore, it is crucial to identify a new and safe drug for preventing or treating IBD [5]. Consequently, many people with IBD turn to alternative medicine including traditional plant based remedies [2].

A number of studies reported that plant-derived extracts or plant derivatives such as phenolic compounds and flavonoids show anti-inflammatory activity by controlling the levels of various inflammatory cytokines or inflammatory mediators including IL-1, IL-6, IL-10, TNF- $\alpha$, NF- $\mathrm{B}$, NO, iNOS and COX-2. Moreover, many crude extracts and chemical constituents of plants have pharmacologic effects and clinical benefits. However, the claims of benefits of many plants or plant based medicines marketed to the general population are only supported by empirical or preliminary scientific data [6].

Therefore, the aim of this review is to provide an overview of the effects of more than 50 natural products used worldwide for the treatment of IBD. For this purpose, electronic databases including Pubmed, Scopus, Embase, and Google Scholar were searched for each of the natural products, and all retrieved plants sited here were examined by in vitro, in vivo, or clinical trials to determine the their efficacy on IBD or related factors.

\section{The Factors of IBD}

The most agreed upon hypothesis currently implicates a combination of one or more factors such as: immune deregulation which is caused by genetic or environmental factors, abnormal gastrointestinal (GI) tract luminal factors (e.g., microorganisms constituting the GI tract flora), oxidative stress, and defects in the GI mucosal barrier that allow luminal factors to penetrate the mucosa [7,8]. However, the specific etiology of IBD is unclear [9]. 


\subsection{Abnormal Immune Response}

Defective responses in both the innate and the adaptive immune systems in IBD are reported [10]. The character of the cells mediating innate immunity such as neutrophils, macrophages, dendritic cells, and natural killer cells are changed and abnormal mucosal $\mathrm{T}$ helper (Th) cell response and over expression of cytokines such as TNF- $\alpha$, interferon- $\gamma$ (IFN- $\gamma$ ), interleukin-1 $\beta$ (IL-1 $\beta$ ), IL-12 as well as IL-6 were found in patients with IBD [11,12]. These changes cause destructive affections of the mucous membrane of the large intestine, e.g., impairment of mucous barrier, swelling, ulcers, erosions, and hemorrhages [13-15]. Cytokines are key signaling molecules of the intestinal immune system, which play an important role in IBD. TNF- $\alpha$ is one of the most important pro-inflammatory cytokines that directly influence intestinal epithelial tissue and Interleukin-1 $\beta$ and IL- 6 are also key mediators of IBD progression [2]. Excessive TNF- $\alpha$ expression results in damaging the epithelial barrier, initiation of apoptosis in epithelial cells, and initiation of chemokine secretion by colonic epithelial cells [2]. In addition, Liu and Wang reported that TNF- $\alpha$ that is released from macrophages during the first stage of inflammation plays a vital role in 2,4,6-trinitrobenzenesulfonic acid (TNBS) - induced colitis and is identically the key controller of the inflammatory flow in this IBD model [16]. An IL-1 receptor antagonist was found to decrease the permeation of inflammatory cells into the large intestine, the MPO activity of cells in areas of edema, and colon necrosis in acute colitis model [17]. Interleukin-6 is related to necrosis in the colon that leads to tissue destruction. Several investigators have reported anti-inflammatory properties of different types of plants or natural compounds by reducing the cytokine expression on in vitro and in vivo model. For example, Inonotus obliquus, grown on germinated brown rice, showed anti-IBD effect and reduced the pro-inflammatory cytokine expression in mice [1]. Inonotus obliquu, Coriolus versicolo and Prunus mume extracts have been found to have anti-IBD effect which likely occurred by the attenuating proinflammatory gene expression, particularly that of TNF- $\alpha$, IL-4, and IL-1ß [18-20].

\subsection{Reactive Oxygen Species}

Oxidative stress is one of most important etiological and/or triggering factor for IBD. The damaging effects of ROS have been well known in the inflammatory process [21-23]. ROS and Reactive nitrogen species (RNS) metabolites are associated with the initiation and progression of IBD [24]. ROS are very unstable because of their high reactivity that occur peroxidation and the oxidative damage to DNA and proteins [25]. Recent studies have found decreased total antioxidant activity and increased ROS in patients with IBD $[22,23,26,27]$. It was demonstrated that the antioxidant activity of some herbs can improve IBD.

\subsection{Microbial Effect}

The roles of microbial content of the GI tract in IBD have already been reported [28]. The interactions between the host susceptibility, mucosal immunity and intestinal microflora are responsible for the pathogenesis of IBD. The composition of the flora in an individual is stable in the human body, but differs between the stomach and upper bowel, lower small bowel, right colon and rectum. Moreover, the flora recovered from feces is also different from mucosa-associated or 
intraepithelial flora [28]. The resident microbiota plays a critical role in modulating the immune response of the gut as well as in the initiation and perpetuation of IBD. Compared to normal, the higher concentration of intestinal bacteria was shown in IBD that increases progressively with disease severity [29]. Therefore, adjusting the gut bacterial flora by antibacterial agents may be beneficial to treat UC [30,31]. Currently, the prebiotics used in the functional food industry are oligosaccharides including lactulose, fructo-oligosaccharides, inulin, galacto-oligosaccharides. The consumption of prebiotics may influence the activity and composition of colonic microbiota. Therefore, a great interest of finding the various prebiotics or mixtures of prebiotics that could play a biological activity throughout the whole colon and reduce the rate of chronic colonic diseases such as Crohn's disease and colorectal cancer. In this regard, specific studies have been carried out to identify potential key ingredients in various medicinal plants known for their ancient uses as healing remedies [32]. The recent study showed that two commercially-available natural polysaccharide supplements modulated microbial community in the different areas of the colon [33].

\subsection{Nuclear Factor-Kappa B}

Nuclear factor-kappa B (NF-kß) protein promotes the expression of more than 150 genes, many of them act as important roles in the regulation of inflammation and programmed cell death (apoptosis) [34,35]. Over expression or inappropriate activation of NF-kB has been shown in human IBD [36,37]. However, the activation of NF-kB is not causative for IBD, but NF-KB seems to play an important role in these diseases [34]. Thus, the inhibitors of NF-kB or IKK can be used as a treatment strategy for managing IBD.

\section{5. iNOS and COX-2}

Under a physiological state, nitric oxide is synthesized from L-arginine with the involvement of constitutive NO synthases - eNOS and nNOS. Large amount of NO-synthases, especially iNOS is indicative of ulcerative colitis [38]. Prostaglandins produced by COX-1 and COX-2, that is another important system involved in the development of ulcerative colitis. Under physiological conditions, COX-1 of mRNA is expressed in the large intestine. At the same time, COX-2 also appears in the interstitial tissue, epithelial cells, and neurons of sub-mucous and inter-muscular plexuses. Increasing amounts of prostaglandins synthesized by COX-2 are involved in the inflammatory process [39].

\section{Modern Evidence for the Efficacy of Plants on IBD}

\subsection{Coriolus versicolor}

Coriolus versicolor is a mushroom belonging to the class Homobasidiomycetes. The ethanol extracts from Coriolus versicolor showed anti-IBD effects. Colitis was induced in male BALb/c mice by giving them drinking water containing dextran-sulfate sodium (DSS). Coriolus versicolor treatment reduced the expression of pro-inflammatory cytokine profile such as TNF- $\alpha$, IL-1 $\beta$ and IL- 6 . It showed a significant reduction in the expression of signal transducers and activators of transcription (STAT) 1 and STAT6 molecules and lower IFN- $\gamma$ and IL-4 expression. The higher immunoglobulin (Ig)A and 
lower IgE levels were found in serum of the DSS + Coriolus versicolor treated group mice compared to DSS treated group [19].

\subsection{Brahmi}

Yamada et al. conducted a comparative study of the immunostimulatory effects of the medicinal herbs Echinacea, Ashwagandha and Brahmi [40]. Among them, Ashwagandha (Withania somnifera) and Brahmi (Bacopa monnieri) are commonly found in India. They compared the immunostimulatory effects of Ashwagandha and Brahmi with the effect of Echinacea and observed the Brahmi diet enhance immune function by increasing the levels of $\operatorname{IgA}$ and $\mathrm{IgG}$ in the serum of male Sprague Dawley rats.

\subsection{Inonotus obliquus}

Inonotus obliquus (IO) is a mushroom belonging to the inonotus genus and Hymenochaetaceae family of Basidiomycetes living as a parasite on birches in Europe and Asia. In Russia, the black, shapeless overgrowth of the birch is usually called chaga [41]. The water extracts of IO suppressed the ulcerative colitis in DSS induced male BALB/c mice [18]. The water extracts decreased the expression of TNF- $\alpha$, IL-4 and STAT1, STAT6 compared to those of the disease group. It also showed the inhibitory activity on LPS induced TNF- $\alpha$, STAT1, pSTAT1, STAT6, and pSTAT6 production in RAW264.7 cells. IO grown on germinated brown rice (IOGBR) ethanol extracts showed potent activity on ulcerative colitis in mice [1]. IOGBR reduced proinflammatory mediators such as tumor necrosis factor (TNF)- $\alpha$, cyclooxygenase (Cox)-2, interleukin (IL)-4, interferon (IFN)- $\gamma$ and decreased STAT1 and STAT6 expression. Immunoglobulins (Ig) act as an important role in inflammation. Therefore, IOGBR extracts suppressed the expression of $\operatorname{IgE}$ and $\operatorname{IgA}$ in the spleen and mesenteric lymph node (MLN) compared to those of the DSS-induced colitis group. The extracts suppressed the pathogenic shortening of colon length and reduced DSS-induced colonic tissue destruction.

\subsection{Cordyceps sinensis}

Cordyceps sinensis is a fungus belonging to the family Clavicipitaceae. The water extracts of Cordyceps sinensis was applied to the $\mathrm{C} 57 \mathrm{Bl} / 6 \mathrm{~N}$ mice to evaluate the effects of immune function of mesenteric lymph node (MLN) lymphocytes. The results indicated that the IgE concentrations in serum and MLN lymphocytes were significantly lower in $C$. sinensis-treated mice than in the control mice. The extracts increased the proportion of $\mathrm{CD} 4\left(^{+}\right)$and $\mathrm{CD} 8\left(^{+}\right) \mathrm{T}$ cells in MLN lymphocytes [42]. Different research found that Cordyceps militaris extract suppresses dextran sodium sulfate-induced acute colitis in BALB/c mice by suppressing disease symptoms such as body weight loss, diarrhea and gross bleeding. The extracts prevented shortening of the colon and crypt length and the epithelial damage [43].

\subsection{Prunus mume}

Prunus mume Sieb. et Zuce belongs to the genus Prunus and family Rosaceae. This fruit known as Ou-mae and has been used in Korea as a folk medicine to treat fever, cough and intestinal disorders [44]. 
In addition, the unripe $P$. mume showed inhibitory activity against Helicobacter pylori motility [45]. Yingsakmongkon et al. studied concentrated fruit juice to prevent or reduce the virus infection in human influenza [46]. Prunate isolated from P. mume has inhibitory activity on the proliferation of cancer cells [46,47]. Antioxidant activities of flowers and fresh fruits of $P$. mume have been examined $[48,49]$. Prunus mume mixture treatment decreased the expression of TNF- $\alpha$, COX-2, IL-4, STAT6, INF- $\gamma$, STAT1 in mice with DSS-induced colitis [20]. In addition, Mume Fructus is the fruit of Prunus mume. The mature green fruit is heated at a low temperature until the yellowish colored pulp changes to brown. Then, the peel wrinkles and is braised until it turns black. The carbonized dried form is preserved and used. The water extracts of Mume Fructus showed 1,1-diphenyl-2-picrylhydrazyl (DPPH), 2,2'-azino-bis(3-ethylbenzthiazoline-6-sulfonic acid) (ABTS), hydroxyl $\left(\mathrm{OH}^{*}\right)$, superoxide $\left(\mathrm{O}_{2}^{-\bullet}\right)$ radicals and nitrite scavenging activities, inhibition of linolic acid oxidation and reducing power activity [50]. Mume Fructus pill (FMP) has been used as a folk medicine in China. For the treatment of gastrointestinal disorders, Mume Fructus pill was approved by the State Food and Drug Administration (SFDA) of China in 2001 (Approval No. Z11021100). From the study of Liu et al. FMP prevented diarrhea, colon weight increase, colonic accretion, ulceration and myeloperoxidase (MPO) activity elevation [51]. The FMP recovered colonic damage and promoted abnormal cytokine secretion in rats with colitis.

\subsection{Gardenia jasminoides}

Gardenia jasminoides Ellis (GJE) is a flowering plant which belongs to the genus Gardenia and family Rubiaceae. It has traditionally been used as folk medicine in many Asian countries. The ethanol and water extracts from Gardenia jasminoides Ellis have been researched to evaluate their antioxidant activity. Both extracts showed high antioxidant activity by scavenging various radicals. The extracts showed strong reducing power, nitrite scavenging activity, linoleic acid oxidation inhibition, superoxide dismutase-like (SOD-like) activity, and catalase activity in vitro [52]. Glycoprotein isolated from Gardenia jasminoides Ellis (GJE) fruits suppressed MPO activity, TBARS level, and NO production and inhibited the over production of iNOS, COX-2, and NF-kappa- $\beta$ (p50) in DSS-induced mice [53].

\subsection{Chrysanthemum indicum}

Chrysanthemum indicum Linné is an herb that belongs to the genus of chrysanthemum and family of Asteraceae. It has traditionally been used as folk medicine in China and Korea and treats various immune-related disorders, hypertension and various infectious diseases including pneumonia, colitis, stomatitis, carbuncle and fever [54,55]. Butanol-soluble fraction of Chrysanthemum indicum inhibited on the auricle edema in mice [54].

\subsection{Benincasa hispida Cogn.}

Waxgourd (Benincasa hispida Cogn.) belongs to a family of Cucurbitaceae and has been used in traditional Chinese medicine to treat inflammation and high blood pressure. It is good for mineral detoxification, lowering fever and strengthening the function of the bladder and small and large 
intestines [56]. The seed extracts of Benincasa hispida inhibits the histamine secretion and show antitumor effects by enhancing immunoreactions [57]. Different parts of the wax gourd such as the peel, core and pulp as well as fresh seeds have antioxidant capacity [58]. Water extract from dry seeds of Benincasa hispida showed strong antioxidant activity by scavenged DPPH, ABTS and hydroxyl radical in a dose-dependent manner [59]. The extracts also showed inhibitory activity on linoleic acid oxidation and nitrite radical [59]. The dried seed extracts produced significant reduction in ulcer index in Wistar albino rats. Further, the extracts reduced MDA content along with increasing CAT levels when compared to the control group [60].

\subsection{Avicennia marina}

Avicennia marina (A. marina) is a plant of the Acanthaceae, commonly known as grey mangrove or white mangrove. A. marina decreased the colonic lipid peroxides, glutathione peroxidase, and serum nitric oxide, lesion score and wet colon weight, and increased the colonic and erythrocyte superoxide dismutase and glutathione levels compared with colitis control [61].

\subsection{Patrinia scabiosaefolia}

Patrinia scabiosaefolia Fisch belongs to the family Valerianaceae. In Asia, the plants are usually used to treat anti-inflammatory diseases, especially for colonic inflammations, virus infections, hepatitis, and uteritis [62]. The root extracts of Patrinia scabiosaefolia Fisch suppressed weight loss, diarrhea, gross bleeding, infiltrations of immune cells, prevented shortening of colon length and enlargement of spleen size, down regulated the abnormal secretions and mRNA expressions in mice with DSS induced colitis [2]. Histological study indicated that the extracts reduced edema, mucosal damage, the loss of crypts [2].

\subsection{Ficus bengalensis Linn.}

Ficus bengalensis Linn. from the family Moraceae is a reputed plant in Ayurvedic medicine. In Ayurvedic literature, it is known as "banayan tree." The milky juice from the stem, seeds, or fruit of this plant is used externally for rheumatism and on the soles of feet when inflamed. It is also used for the treatment of dysentery and diarrhea. The ethanol extracts from the bark of this tree declined colon mucosal damage index and disease activity index and decreased the MPO, MDA, NO, and increased the SOD activity in the colons of rats with IBD [63].

\subsection{Ginger (Zingiber officinale)}

Ginger, belongs to the family Zingiberaceae, and its component zingerone were investigated to determine its anti-inflammatory activity in mice colitis induced by TNBS. They ameliorated TNBS-induced colonic injury in a dose-dependent manner. Their pathway investigation on gene expression profiles has been found to control cytokine-related pathways significantly. They suppressed TNBS-induced NF- $\kappa$ B activation and IL-1 $\beta$ protein level in the colon [64]. 


\subsection{Withania somnifera}

Withania somnifera (Dunal), belongs to the family Solanaceae, is used as a medicine since 2500 years in Indian medicinal classic "Ayurveda". Aqueous extract of its the root showed anti-oxidant activity by reducing $\mathrm{H}_{2} \mathrm{O}_{2}$ and NO. It has lipid peroxidation inhibition activity. The extracts scored positively on histopathological parameters like necrosis, edema, neutrophil infiltration in TNBS-induced IBD rat model [65].

\subsection{Garcinia cambogia}

Garcinia cambogia, known as Malabar tamarind, is native to Southeast Asia. Its fruit extracts have been suggested to have a variety of pharmacological properties including antiulcer activities. The anti-inflammatory activity of a garcinia extract was assessed in TNBS-induced colitis rats. The extracts treatment improved the macroscopic damage and reduced MPO activity, COX-2 and iNOS expression. It was also able to reduce PGE2 and IL-1 $\beta$ colonic levels. It did not show any mortality nor toxicity signals after oral administration [66].

\section{In vitro Studies of Plant on IBD Related Factors}

Scouring rush (Equisetum hyemale L.) is a perennial herb belong to the family Equisetaceae. [67]. Different extracts of this plant showed antioxidant and anti-inflammatory activities. The extracts have reducing power, metal-chelating activity, superoxide and nitrite scavenging abilities. The extracts showed inhibitory activity on NO, iNOS and COX-2 production in RAW 264.7 macrophages [67]. Schizonepeta tenuifolia is an herb belonging to the family of Lamiaceae. The methanol extracts from this plant showed inhibitory activity on iNOS in LPS-stimulated RAW 264.7 cells with highly antioxidant properties [68]. Antrodia salmonea T. T. Chang et W. N. Chou (Polyporaceae), a new species of the genus Antrodia, identified in 2004 [69]. Ethanol extracts from this plant showed nitric oxide (NO) production, expression of inducible nitric oxide synthase (iNOS) and COX-2 proteins inhibition and enzymatic antioxidant activity [70].

\section{Conclusions}

A great deal of evidence suggests that chronic inflammation promotes development of numerous human diseases, including IBD. Various herbal products have been used for the treatment of IBD. In this review we found that these natural products have shown their usefulness in IBD by different mechanisms of action such as inhibiting the production of NO, Cox-2, immunomodulatory properties, antimicrobial activities, antioxidant activities, and antiulcer properties which are summarized in detail in Tables 1 and 2. As shown in Table 1, some of these plants showed only one or two mechanisms of action such as in Bacopa monnieri, Vaccinium myrtillus, Coriolus versicolor, Inonotus obliquus. However, in some of the plants, various mechanisms of action are shown. For example Garcinia cambogia and liquorice are effective in IBD for their pro-inflammatory cytokines and NO and Cox-2 inhibitory and antioxidant properties. Considering the devices of action of these plants, the mixture or combination of some of them may be beneficial due the numerous mechanisms involved in IBD. Based on the some in vitro studies, some plants are more effective to reduce IBD related factors. For 
example, Taiwanofungus salmoneus have antibacterial and NO, TNF- $\alpha$ scavenging activities, Labisia pumila var. pumila, Labisia pumila var. alata, Labisia pumila var. lanceolata have NO, antifungal, and anticancer activities, Artemisia herba-alba, Ruta chalpensis L, Peganum harmala L have anti-oxidant, anti-cancer, and anti-inflammatory activities. However, the exact mechanisms behind the anti-IBD effects of some of these natural products are still unclear. Therefore, additional in vivo research will be needed to determine their effects and to find which specific factors are involved in improving IBD in humans.

Table 1. In vivo studies on plants medicine for the treatment of inflammatory bowel disease.

\begin{tabular}{|c|c|c|c|c|c|}
\hline Study & Plant & Part & Model & Species & Results \\
\hline Debnath et al. [1] & $\begin{array}{l}\text { Inonotus obliquus } \\
\text { on germinated } \\
\text { brown rice }\end{array}$ & $\begin{array}{c}\text { Total } \\
\text { mushroom }\end{array}$ & DSS & Mice & 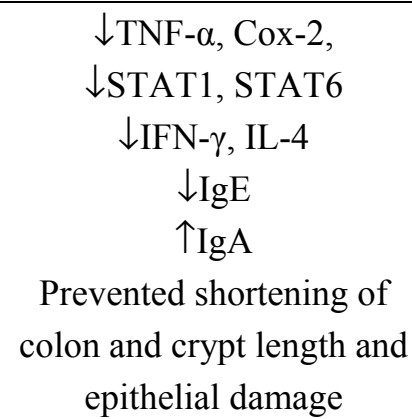 \\
\hline Cho et al. [2] & $\begin{array}{c}\text { Patrinia } \\
\text { scabiosaefolia }\end{array}$ & Root & DSS & ICR mice & $\begin{array}{c}\downarrow \text { Weight loss, diarrhea, } \\
\text { gross bleeding, infiltrations } \\
\text { of immune cells. } \\
\downarrow \text { TNF- } \alpha \text {, IL-1 } \beta \text {, and IL-6 } \\
\text { mRNA level }\end{array}$ \\
\hline Lim et al. [18] & Coriolus versicolor & $\begin{array}{c}\text { Total } \\
\text { mushroom }\end{array}$ & DSS & mice & $\begin{array}{c}\downarrow \text { TNF- } \alpha, \text { IL-1 } \beta, \text { IL-6 } \\
\downarrow \text { STAT1, STAT6 } \\
\downarrow \text { IFN- } \gamma, \text { IL-4 } \\
\downarrow \text { IgE } \\
\uparrow \operatorname{IgA} \\
\end{array}$ \\
\hline Choi et al. [19] & Inonotus obliquus & $\begin{array}{c}\text { Total } \\
\text { mushroom }\end{array}$ & DSS & mice & $\begin{array}{c}\downarrow \downarrow \text { TNF- } \alpha, \\
\downarrow \text { STAT1, STAT6 }\end{array}$ \\
\hline Jin et al. [20] & Prunus mume & Mixture & DSS & mice & $\begin{array}{c}\downarrow \text { TNF- } \alpha \text {, Cox- } 2, \\
\downarrow \text { STAT1, STAT6 } \\
\downarrow \text { IFN- } \gamma, \text { IL-4 } \\
\downarrow \text { IgE } \\
\uparrow \text { IgA } \\
\text { Prevented shortening of } \\
\text { colon and crypt length and } \\
\text { epithelial damage }\end{array}$ \\
\hline $\begin{array}{c}\text { Yamada et al. } \\
{[40]}\end{array}$ & $\begin{array}{c}\text { Bacopa monnieri } \\
\text { (Brahmi) }\end{array}$ & Herb & & rat & $\downarrow_{\operatorname{IgA}}$ and $\operatorname{IgG}$ in the serum \\
\hline Park et al. [42] & Cordyceps sinensis & Mushroom & & $\begin{array}{l}\mathrm{C} 57 \mathrm{Bl} / 6 \mathrm{~N} \\
\text { mice }\end{array}$ & $\begin{array}{c}\downarrow \mathrm{IgE} \text { in serum and MLN } \\
\uparrow \mathrm{CD} 4\left(^{+}\right) \text {and } \mathrm{CD} 8\left(^{+}\right) \\
\text {proportion in MLN. }\end{array}$ \\
\hline Han et al. [43] & Cordyceps militaris & Mushroom & DSS & mice & $\begin{array}{l}\text { Prevented shortening of } \\
\text { colon and crypt length and } \\
\text { epithelial damage. }\end{array}$ \\
\hline
\end{tabular}


Table 1. Cont.

\begin{tabular}{|c|c|c|c|c|c|}
\hline Study & Plant & Part & Model & Species & Results \\
\hline Liu et al. [51] & $\begin{array}{l}\text { Mume Fructus } \\
\text { (Prunus mume) }\end{array}$ & Fruits & TNBS & Rat & $\begin{array}{c}\downarrow \text { diarrhea, colonic } \\
\text { accretion, ulceration, } \\
\downarrow_{\text {IFN- } \gamma, \text { IL-4 }}\end{array}$ \\
\hline Rise et al. [61] & Avicennia marina & Plant & acetic acid & Mice & $\begin{array}{c}\downarrow \text { Colonic lipid peroxides, } \\
\text { serum nitric oxide. } \\
\uparrow \text { SOD and glutathione } \\
\text { levels }\end{array}$ \\
\hline Patel et al. [63] & Ficus bengalensis & Bark & TNBS & Wistar rats & $\begin{array}{c}\downarrow \mathrm{MPO}, \mathrm{MDA}, \mathrm{NO} \\
\uparrow \mathrm{SOD} \\
\end{array}$ \\
\hline Hsiang et al [64] & $\begin{array}{c}\text { ginger } \\
\text { (Zingiber } \\
\text { officinale) }\end{array}$ & Zingerone & TNBS & mice & $\begin{array}{c}\downarrow \text { NF- } \kappa \text { B activity and IL-1 } \beta \\
\text { signalling pathway }\end{array}$ \\
\hline Pawar et al. [65] & $\begin{array}{l}\text { Withania } \\
\text { somnifera }\end{array}$ & Root & TNBS & Rat & $\begin{array}{c}\text { Positively scored on } \\
\text { histopathological } \\
\text { parameters, } \\
\text { lipid peroxidation, } \mathrm{H} 2 \mathrm{O} 2 \\
\text { nad NO scavenging } \\
\text { activities. }\end{array}$ \\
\hline $\begin{array}{l}\text { Rosillo et al. } \\
\text { [71] }\end{array}$ & Punica granatum & Polyphenols & TNBS & Rat & $\begin{array}{c}\downarrow_{\mathrm{iNOS}, \mathrm{COX}-2, \mathrm{p} 38, \mathrm{JNK}} \\
\text { pERK1/2, IKB } \alpha \text { and } \\
\text { nuclear p65 NF-кB }\end{array}$ \\
\hline Jagtap et al. [72] & $\begin{array}{c}\text { Bombax } \\
\text { malabaricum }\end{array}$ & $\begin{array}{l}\text { Phytochemic } \\
\text { als }\end{array}$ & $\begin{array}{l}\text { indometha } \\
\text { cin and } \\
\text { iodoaceta } \\
\text { mide, } \\
\text { acetic acid }\end{array}$ & $\begin{array}{l}\text { Rat, } \\
\text { mice }\end{array}$ & $\begin{array}{c}\downarrow \downarrow \text { Ulcer score and MPO } \\
\downarrow \downarrow \text { TNF- } \alpha\end{array}$ \\
\hline Jung et al. [73] & $\begin{array}{c}\text { Apples } \\
\text { (Malus spp) } \\
\end{array}$ & polyphenol & & & $\begin{array}{c}\downarrow \text { Proinflammatory gene } \\
\text { expression } \\
\end{array}$ \\
\hline Dost et al.[74] & Garcinia kola & Herb & TNBS & Rat & $\begin{array}{c}\downarrow \text { Colonic damage } \\
\uparrow \text { Antioxidant enzymes }\end{array}$ \\
\hline
\end{tabular}

TNBS: 2,4,6-Trinitrobenzene sulfonic acid; DSS: Dextran-sulfate sodium, IL: Interleukin; NF-kB: Nuclear factor $\kappa B$; IFN: Interferon; NO: Nitric oxide; TNF- $\alpha$ : Tumor necrosis factor $\alpha$; iNOS: Inducible nitric oxide synthase; Cox: Cyclooxygenase, MPO: myeloperoxide; Ig: Immunoglobulin; STAT: signal transducer and activator of transcription, ERK: Extracellular signalregulated kinase, JNK: c-Jun NH2-terminal kinase; PGE2: Prostaglandin E2; SOD: Superoxide dismutase; CAT: Catalase; MDA: Malondialdehyde.

Table 2. In vitro studies of plants medicine and their target on IBD-related factors.

\begin{tabular}{|c|c|c|c|}
\hline Study & Plant & Part/extracts & Results \\
\hline Debnath et al. $[50]$ & Mume Fructus (Prunus mume) & Fruits & Antioxidant activity \\
\hline Debnath et al. [52] & Gardenia jasminoides Ellis & Fruits & Antioxidant activity \\
\hline Samad et al. [59] & Benincasa hispida & Seed & Antioxidant activity \\
\hline Triebel et al. $[$ [5] & Vaccinium myrtillus & Plant & $\begin{array}{c}\downarrow \text { Pro-inflammatory } \\
\text { mediators }\end{array}$ \\
\hline
\end{tabular}


Table 2. Cont.

\begin{tabular}{|c|c|c|c|}
\hline Study & Plant & Part/extracts & Results \\
\hline Edmunds et al. [76] & $\begin{array}{l}\text { Actinidia chinensis } \\
\text { Actinidia deliciosa }\end{array}$ & Fruit & $\downarrow \mathrm{NO}$ and cytokine secretion \\
\hline Zia-Ul-Haq et al. [77] & $\begin{array}{c}\text { Black gram (Vigna mungo L.), } \\
\text { Green gram (Vigna radiate) } \\
\text { soybean (Glycine max.) } \\
\text { lentil (Lens culinaris Medik) }\end{array}$ & Seed & $\downarrow \mathrm{COX}_{2}, \mathrm{PGE}_{2}$ \\
\hline \multirow[t]{23}{*}{ Mueller et al. [78] } & Allspice (Pimenta officinalis) & Fruit & \multirow{23}{*}{$\begin{array}{c}\downarrow \mathrm{COX} 2, \text { TNF-alpha and IL-6 } \\
\uparrow \mathrm{IL}-10\end{array}$} \\
\hline & Anise (Pimpinella anisum) & Fruit & \\
\hline & Basil (Ocimum basilicum) & Leaves & \\
\hline & Bay leaves (Laurus nobilis) & Leaves & \\
\hline & Bilberry (Vaccinium myrtillus) & $\begin{array}{c}\text { Phenols, } \\
\text { (anthocyanins) }\end{array}$ & \\
\hline & Black pepper (Piper nigrum) & Fruit & \\
\hline & Cacao (Theobroma cacao) & Seed & \\
\hline & Caraway (Carum carvi) & Seed & \\
\hline & Cardamom (Elettaria cardamomum) & Seed & \\
\hline & Chili pepper (Capsicum annuum) & Fruit & \\
\hline & Cinnamon (Cinnamomum cassia) & Bark & \\
\hline & Clove (Syzygium aromaticum) & Flower & \\
\hline & Coriandrum sativum & Seed & \\
\hline & Zingiber officinale & Rhizomes & \\
\hline & Lemon grass( Cymbopogon citratus) & Leaves & \\
\hline & Licorice ( Glycyrrhiza glabra) & Root & \\
\hline & Marjoram (Origanum majorana) & Leaves & \\
\hline & Nutmeg (Myristica fragrans) & Fruits & \\
\hline & Oregano (Origanum onites) & Leaves & \\
\hline & Paprika (Capsicum annuum) & Fruits & \\
\hline & Rooibos tea (Aspalathus linearis) & Leaves & \\
\hline & Rosemary (Rosmarinus officinalis) & Plant & \\
\hline & Sage (Salvia officinalis) & Leaves & \\
\hline Jedinak et al. [79] & Oyster mushroom (Pleurotus ostreatus) & $\begin{array}{l}\text { Mushroom } \\
\text { concentrate }\end{array}$ & $\begin{array}{c}\downarrow \mathrm{COX}-2 \text { and iNOS, } \\
\downarrow \text { NF- } \kappa \mathrm{B}, \mathrm{AP}-1\end{array}$ \\
\hline Chiang et al. [80] & Taiwanofungus salmoneus & Mycelia & $\begin{array}{c}\text { Antibacterial activity } \\
\downarrow \downarrow N O, T N F-\alpha\end{array}$ \\
\hline Ruangnoo et al. [81] & Smilax corbularia & Plant & $\downarrow$ NO, TNF- $\alpha$ and PGE2 \\
\hline Karimi et al. [82] & $\begin{array}{c}\text { Labisia pumila var. pumila } \\
\text { Labisia pumila var. alata } \\
\text { Labisia pumila var. lanceolata }\end{array}$ & Leaves and roots & $\begin{array}{c}\downarrow \downarrow \mathrm{NO} \\
\text { Antifungul, and anticancer } \\
\text { activity }\end{array}$ \\
\hline Khlifi et al. [83] & $\begin{array}{c}\text { Artemisia herba-alba, } \\
\text { Ruta chalpensis } L, \\
\text { Peganum harmala L. }\end{array}$ & Leaves & $\begin{array}{c}\text { Anticancer, } \\
\text { Antioxidant (DPPH, ABTS } \\
\text { radical scavenging activity) } \\
\text { Anti-inflammatory activities } \\
\quad(\downarrow \text { iNOS mRNA })\end{array}$ \\
\hline
\end{tabular}


Table 2. Cont.

\begin{tabular}{|c|c|c|c|}
\hline Study & Plant & Part/extracts & Results \\
\hline $\begin{array}{c}\text { Jiménez-Estrada et al. } \\
\text { [84] }\end{array}$ & $\begin{array}{c}\text { Krameria erecta, } \\
\text { Struthanthus palmeri, Phoradendron } \\
\text { californicum, Senna covesii } \\
\text { Stegnosperma halimifolium }\end{array}$ & Plant & $\begin{array}{l}\text { Anti-oxidant and } \\
\text { antiproliferative activities }\end{array}$ \\
\hline Han et al. [85] & Artemisia capillaris & Capillarisin & 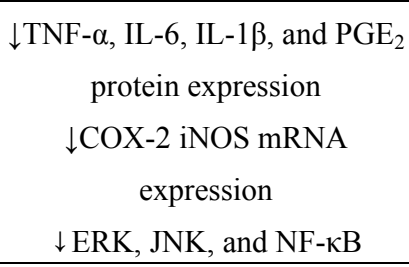 \\
\hline Choe et al. [86] & Rhodiola sachalinensis & $\begin{array}{c}\text { Phenolic } \\
\text { compounds from } \\
\text { root }\end{array}$ & $\begin{array}{l}\text { Anti-oxidant activity } \\
\text { NO scavenging activity }\end{array}$ \\
\hline Bang et al. [87] & Achyranthes japonica & Root & $\begin{array}{c}\downarrow N O, \text { iNOS, ERK, JNK, P38, } \\
\text { NF-кB }\end{array}$ \\
\hline Chae et al. [88] & Hylomecon hylomeconoides & Ethanol extracts & $\downarrow \mathrm{NO}, \mathrm{IL}-6, \mathrm{ERK} 1 / 2, \mathrm{p} 38$ \\
\hline Debnath et al. [89] & Chrysanthemum indicum & Flower & Antioxidant activity \\
\hline
\end{tabular}

IL: Interleukin; NF-кB: Nuclear factor $\kappa B$; IFN: Interferon; NO: Nitric oxide; TNF- $\alpha$ : Tumor necrosis factor $\alpha$; iNOS: Inducible nitric oxide synthase; Cox: Cyclooxygenase, ERK: Extracellular signalregulated kinase, JNK: c-Jun NH2-terminal kinase; PGE2: Prostaglandin E2.

\section{Acknowledgements}

This research was supported by Basic Science Research Program through the National Research Foundation of Korea (NRF) and funded by the Ministry of Education, Science and Technology (2011-0022244).

\section{Conflict of Interest}

The authors declare no conflict of interest.

\section{References}

1. Debnath, T.; Hasnat, M.A.; Pervin, M.; Lee, S.Y.; Park, S.R.; Kim, D.H.; Kweon, H.J.; Kim, J.M.; Lim, B.O. Chaga mushroom (Inonotus obliquus) grown on germinated brown rice suppresses inflammation associated with colitis in mice. Food Sci. Biotechnol. 2012, 21, $1235-1241$.

2. Cho, E.-J.; Shin, J.-S.; Noh, Y.-S.; Cho, Y.-W.; Hong, S.-J.; Park J.-H.; Lee, J.Y.; Lee, J.-Y.; Lee, K.-T. Anti-inflammatory effects of methanol extract of Patrinia scabiosaefolia in mice with ulcerative colitis. J. Ethnopharmacol. 2011, 136, 428-435.

3. Jani, N.; Regueiro, M.D. Medical therapy for ulcerative colitis. Gastroenterol. Clin. N. Am. 2002, 31, 147-166.

4. Lakatos, P.L.; Lakatos, L. Ulcerative proctitis: A review of pharmacotherapy and management. Expert. Opin. Pharmacother. 2008, 9, 741-749. 
5. Sergent, T.; Piront, N.; Meurice, J.; Toussaint, O.; Schneider, Y.-J. Anti-inflammatory effects of dietary phenolic compounds in an in vitro model of inflamed human intestinal epithelium. Chem. Biol. Interact. 2010, 188, 659-667.

6. Koretz, R.L.; Rotblatt, M. Complementary and alternative medicine in gastroenterology: The good, the bad, and the ugly. Clin. Gastroenterol. Hepatol. 2004, 2, 957-677.

7. Kucharzik, T.; Maaser, C.; Lugering, A.; Kagnoff, M.; Mayer, L.; Targan, S.; Domschke, W. Recent understanding of IBD pathogenesis: Implications for future therapies. Inflamm. Bowel. Dis. 2006, 12, 1068-1083.

8. Scaldaferri, F.; Fiocchi, C. Inflammatory bowel disease: Progress and current concepts of tiopathogenesis. J. Dig. Dis. 2007, 8, 171-178.

9. Ye, B.M.; Lim, B. Dietary Pectin Regulates the Levels of Inflammatory Cytokines and Immunoglobulins in Interleukin-10 Knockout Mice. J. Agric. Food Chem. 2010, 58, 11281-11286.

10. Brown, S.J.; Mayer, L. The immune response in inflammatory bowel disease. Am. J. Gastroenterol. 2007, 102, 2058-2069.

11. Ince, M.N.; Elliott, D.E. Immunologic and molecular mechanisms in inflammatory bowel disease. Surg. Clin. N. Am. 2007, 87, 681-696.

12. Elsässer-Beile, U.; von Kleist, S.; Gerlach, S.; Gallati, H.; Mönting, J.S. Cytokine production in whole blood cell cultures of patients with Crohn's disease and ulcerative colitis. J. Clin. Lab. Anal. 1994, 8, 447-451.

13. Sklyarov, A. Ya.; Panasyuk, N.B.; Fomenko, I.S. Role of nitric oxide-synthase and cyclooxygenase/lipooxygenase systems in development of experimental ulcerative colitis. J. Physiol. Pharmacol. 2011, 62, 65-73.

14. Hosoi, T.; Goto, H.; Arisawa, T.; Niwa, Y.; Okada, N.; Ohmiya, N.; Hayakawa, T. Role of nitric oxide synthase inhibitor in experimental colitis induced by 2,4,6- trinitrobenzene sulphonic acid in rats. Clin. Exp. Pharmacol. Physiol. 2001, 28, 9-12.

15. Martin, A.R.; Villegas, I.; Alarcon, de. La.; Lastra, C. The COX-2 inhibitor, rofecoxib, ameliorates dextran sulphate sodium induced colitis in mice. Inflamm. Res. 2005, 54, 145-151.

16. Liu, X.; Wang, J. Anti-inflammatory effects of iridoid glycosides fraction of Folium syringae leaves on TNBSinduced colitis in rats. J. Ethnopharmacol. 2011, 133, 780-787.

17. Dionne, S.; D’Agata, D.D.; Hiscott, J.; Vanounou, T.; Seidman, E.G. Colonic explant production of IL-1 and its receptor antagonist is imbalanced in inflammatory bowel disease (IBD). Clin. Exp. Immunol. 1998, 112, 435-442.

18. Choi, S.Y.; Hur, S.J.; An, C.S.; Jeon, Y.H.; Jeoung, Y.J.; Bak, J.P.; Lim, B.O. Anti-inflammatory effects of Inonotus obliquus in colitis induced by dextran sodium sulfate. J. Biomed. Biotechnol. 2010, doi:10.1155/2010/943516.

19. Lim, B.O. Coriolus versicolor Suppresses Inflammatory Bowel Disease by Inhibiting the Expression of STAT1 and STAT6 Associated with IFN- $\gamma$ and IL-4 Expression. Phytother. Res. 2011, 25, 1257-1261.

20. Jin, H.-L.; Lee, B.-R.; Lim, K.-J.; Debnath, T.; Shin, H.-M.; Lim, B.-O. Anti-Inflammatory Effects of Prunus mume Mixture in Colitis Induced by Dextran Sodium Sulfate. Korean J. Med. Crop Sci. 2011, 19, 16-23. 
21. Rezaie, A.; Parker, R.D.; Abdollahi, M. Oxidative stress and pathogenesis of inflammatory bowel disease: an epiphenomenon or the cause? Dig. Dis. Sci. 2007, 52, 2015-2021.

22. Lih-Brody, L.; Powell, S.R.; Collier, K.P.; Reddy, G.M.; Cerchia, R.; Kahn, E.; Weissman, G.S.; Katz, S.; Floyd, R.A.; McKinley, M.J.; et al. Increased oxidative stress and decreased antioxidant defenses in mucosa of inflammatory bowel disease. Dig. Dis. Sci. 1996, 41, 2078-2086.

23. Jahanshahi, G.; Motavasel, V.; Rezaie, A.; Hashtroudi, AA.; Daryani, NE.; Abdollahi, M. Alterations in antioxidant power and levels of epidermal growth factor and nitric oxide in saliva of patients with inflammatory bowel diseases. Dig. Dis. Sci. 2004, 49, 1752-1757.

24. Cross, R.K.; Wilson, K.T. Nitric oxide in inflammatory bowel disease. Inflamm. Bowel Dis. 2003, 9, 179-89.

25. Beckman, K.B.; Ames, B.N. Oxidative decay of DNA. J. Biol. Chem. 1997, 272, 19633-19636.

26. Shiratora, Y.; Aoki, S.; Takada, H.; Kiriyama, H.; Ohto, K.; Hai, K.; Teraoka, H.; Matano, S.; Matsumoto, K.; Kamii, K. Oxygen-derived free radical generating capacity of polymorphonuclear cells in patients with ulcerative colitis. Digestion 1989, 44, 163-171.

27. Buffinton, G.D.; Doe, W.F. Altered ascorbic acid status in the mucosa from inflammatory bowel disease patients. Free Radic. Res. 1995, 22, 131-143.

28. Marteau, P.; Lepage, P.; Mangin, I.; Suau, A.; Doré, J.; Pochart, P.; Seksik, P. Gut Flora and Inflammatory Bowel Disease. Aliment. Pharmacol. Ther. 2004, 20, 18-23.

29. Swidsinski, A.; Ladhoff, A.; Pernthaler, A.; Swidsinski, S.; Loening-Baucke, V.; Ortner, M.; Weber J.; Hoffmann, U.; Schreiber, S.; Dietel, M.; Lochs, H. Mucosal flora in inflammatory bowel disease. Gastroenterol. 2002, 122, 44-54.

30. Rahimi, R.; Nikfar, S.; Rezaie, A.; Abdollahi, M. A meta-analysis of broad-spectrum antibiotic therapy in patients with active Crohn's disease. Clin. Ther. 2006, 28, 1983-1988.

31. Rahimi, R.; Nikfar, S.; Rezaie, A.; Abdollahi, M. A metaanalysis of antibiotic therapy for active ulcerative colitis. Dig. Dis. Sci. 2007, 52, 2920-2925.

32. Eshun, K.; He, Q. 2004. Aloe vera: a valuable ingredient for the food, pharmaceutical and cosmetic industries - a review. Crit. Rev. Food Sci. Nutr. 2004, 44, 91-96.

33. Marzorati, M.; Verhelst, A.; Luta, G.; Sinnott, R.; Verstraete, W.; Van de Wiele, T.; Possemiers, S. In vitro modulation of the human gastrointestinal microbial community by plant-derived polysaccharide-rich dietary supplements. Int. J. Food Microbiol. 2010, 139, 168-176.

34. Kumar, A.; Takada, Y.; Boriek, A.M.; Aggarwal, B.B. Nuclear factor-kappaB: Its role in health and disease. J. Mol. Med. 2004, 82, 434-448.

35. Egan, L.J.; Toruner, M. NF-kappaB signaling: Pros and cons of altering NF-kappaB as a therapeutic approach. Ann. NY Acad. Sci. 2006, 1072, 114-122.

36. Schreiber, S.; Nikolaus, S.; Hampe, J. Activation of nuclear factor kappa B inflammatory bowel disease. Gut 1998, 42, 477-484.

37. Andresen, L.; Jørgensen, V.L.; Perner, A.; Hansen, A.; Eugen-Olsen, J.; Rask-Madsen, J. Activation of nuclear factor kappaB in colonic mucosa from patients with collagenous and ulcerative colitis. Gut 2005, 54, 503-509.

38. Beck, P.L.; Xavier, R.; Wong, J.; Ezedi, I.; Mashimo, H.; Mizoguchi, A.; Mizoguchi, E.; Bhan, A.K.; Podolsky, D.K. Paradoxical roles of different nitric oxide synthase isoforms in colonic injury. Am. J. Physiol. 2004, 286, G137-G147. 
39. Singh, V.; Patil, C.; Jain, N.; Singh, A.; Kulkarni, S.K. Effect of nimesulide on acetic acid- and leukotriene-induced inflammatory bowel disease in rats. Prostaglandins Other Lipid Mediat. 2003, 71, 163-175.

40. Yamada, K.; Hung, P.; Park, T.K.; Park, P.J.; Lim, B.O. A comparison of the immunostimulatory effects of the medicinal herbs Echinacea, Ashwagandha and Brahmi. J. Ethnopharmal. 2011, 137, 231-235.

41. Debnath, T.; Park, D.K.; Lee, B.R.; Jin, H.L.; Lee, S.Y.; Samad, N.B.; Lim, B.O. Antioxidant activity of Inonotus obliquus grown on germinated brown rice extracts. J. Food Biochem. 2011, doi:10.1111/j.1745-4514.2012.00658.x.

42. Park, D.K.; Choi, W.S.; Park, P.J.; Kim, E.K.; Jeong, Y.J.; Choi, S.Y.; Yamada, K.; Kim, J.D.; Lim, B.O. Immunoglobulin and cytokine production from mesenteric lymph node lymphocytes is regulated by extracts of Cordyceps sinensis in C57B1/6N mice. J. Med. Food. 2008, 11, 784-788.

43. Han, E.S.; Oh, J.Y.; Park, H.-J. Cordyceps militaris extract suppresses dextran sodium sulfate-induced acute colitis in mice and production of inflammatory mediators from macrophages and mast cells. J. Ethnopharmacol. 2011, 134, 703-710.

44. Chuda, Y.; Ono, H.; Ohnishi-Kameyama, M.; Matsumoto, K.; Nagata, T.; Kikuchi. Y. Mumefural, Citric acid derivative improving blood fluidity from fruit-juice concentrate of Japanese apricot (Prunus mume Sieb. et Zucc). J. Agric. Food Chem. 1999, 47, 828-883.

45. Miyazawa, M.; Utsunomiya, H.; Inada, K.-I.; Yamada, T.; Okuno, Y.; Tanaka, H; Tatematsu, M. Inhibition of Helicobacter pylori motility by $(+)$-syringaresinol from unripe Japanese apricot. Biol. Pharm. Bull. 2006, 29, 172-173.

46. Yingsakmongkon, S.; Miyamoto, D.; Sriwilaijaroen, N.; Fujita, K.; Matsumoto, K.; Jampangern, W.; Hiramatsu, H.; Guo, C.-T.; Sawada, T.; Takahashi, T.; et al. In vitro inhibition of human influenza A virus infection by fruit-juice concentrate of Japanese plum (Prunus mume SIEB. et ZUCC). Biol. Pharm. Bull. 2008, 31, 511-515.

47. Jeong, J.T.; Moon, J.-H.; Park, K.-H.; Shin, C.S. Isolation and characterization of a new compound from Prunus mume fruit that inhibits cancer cells. J. Agric. Food Chem. 2006, 54, 2123-2128.

48. Shi, J.; Gong, J.; Liu, L.; Wu, X.; Zhan, Y. Antioxidant capacity of extract from edible flowers of Prunus mume in China and its active components. Food Sci. Technol. 2009, 42, 477-482.

49. Chen, R.-Y.; Yang, H.-T.; Tsai, M.-J.; Lin, S.-B. Antioxidant activity and amygdalin contents of Mei (Prunus mume seibu. et Zucc.) flower and fruit water extract at different maturity. Taiwan J. Agric. Chem. Food Sci. 2006, 44, 390-396.

50. Debnath, T.; Bak, J.P.; Samad, N.B.; Jin, H.L.; Lee B.M.; Lim, B.O.J. Antioxidant activity of mume fructus extract. Food Biochem. 2012, 36, 224-232.

51. Liu, L.; Yuan, S.; Sun, Y.; Long, Y.; Li, Y.; Niu, Y.; Li, C.; Gan, H.; Cao, S.; Meia, Q. The possible mechanisms of Fructus Mume pill in the treatment of colitis induced by 2,4,6-trinitrobenzene sulfonic acid in rats. J. Ethnopharmacol. 2009, 126, 557-564.

52. Debnath, T.; Pyo-Jam Park, P. -J.; Deb Nath, N.C.; Samad. N.B.; Park, H.W.; Lim, B.O. Antioxidant activity of Gardenia jasminoides Ellis fruit extracts. Food. Chem. 2011, 128, 697-703.

53. Oh, P.S.; Lim, K.T. Plant originated glycoprotein has anti-oxidative and anti-inflammatory effects on dextran sulfate sodium-induced colitis in mouse. J. Biomed. Sci. 2006, 13, 549-560. 
54. Cheng W, Li J, You T, Hu, C. Anti-inflammatory and immunomodulatory activities of the extracts from the inflorescence of Chrysanthemum indicum Linné. J. Ethnopharmacol. 2005, 101, 334-337.

55. Shunying, Z.; Yang, Y.; Huaidong, Y.; Yue, Y.; Guolin, Z. Chemical composition and antimicrobial activity of the essentialoils of Chrysanthemum indicum. J. Ethnopharmacol. 2005, 96, 151-158.

56. Lee, K.-H.; Choi, H.-R.; Kim, C.-H. Anti-angiogenic effect of the seed extract of Benincasa hispida Cogniaux. J. Ethnopharmacol. 2005, 97, 509-513.

57. Yoshizumi, S.; Murakami, T.; Kadoya, M.; MAtsuda, H.; yamahara, J.; Yoshikawa, M. Medicinal foodstuffs. XI. Histamine release inhibitors from wax gourd, the fruits of Benincasa hispida Cogn. Yakugaku Zasshi 1998, 118, 188-192.

58. Huang, H.-Y.; Huang, J.-J.; Tso, T.K.; Tsai, Y.-C.; Chang, C.-K. Antioxidant and angiotensionconverting enzyme inhibition capacities of various parts of Benincasa hispida (wax gourd). Nahrung 2004, 48, 230-233.

59. Samad, N.B.; Debnath, T.; Jin, H.L.; Lee, B.R.; Park, P.J.; Lee, S.Y.; Lim, B.O. Antioxidant activity of benincasa hispida seeds. Food Biochem. 2011, doi:10.1111/j.1745-4514.2011.00643.x.

60. Rachchh, M.A.; Jain, S.M. Gastroprotective effect of Benincasa hispida fruit extract. Indian J. Pharmacol. 2008, 40, 271-275.

61. Rise, C.L.; Prabhu, V.V.; Guruvayoorappan, C. Effect of marine mangrove Avicennia marina (Forssk.) Vierh against acetic acid-induced ulcerative colitis in experimental mice. J. Environ. Pathol. Toxicol. Oncol. 2012, 31, 179-192.

62. Shin, M.K. Clinical Traditional Herbalogy; Young-Lim Press: Seoul, Korea, 1998; pp. 564-565.

63. Patel, M. A.; Patel, P. K.; Patel, M. B. Effects of ethanol extract of Ficus bengalensis (bark) on inflammatory bowel disease. Indian J. Pharmacol. 2010, 42, 214-218.

64. Hsiang, C.Y.; Lo, H.Y.; Huang, H.C.; Li, C.C.; Wu, S.L.; Ho, T.Y. Ginger extract and zingerone ameliorated trinitrobenzene sulphonic acid-induced colitis in mice via modulation of nuclear factor- $\kappa \mathrm{B}$ activity and interleukin-1 $\beta$ signalling pathway. Food Chem. 2013, 136, 170-177.

65. Pawar, P.; Gilda, S.; Sharma, S.; Jagtap, S.; Paradkar, A.; Mahadik, K.; Ranjekar, P.; Harsulkar A. Rectal gel application of Withania somnifera root extract expounds anti-inflammatory and muco-estorative activity in TNBS-induced inflammatory bowel disease. BMC Complement Altern. Med. 2011, 28, 11-34.

66. dos Reis, S.B.; de Oliveira, C.C.; Acedo, S.C.; Miranda, D.D.; Ribeiro, M.L.; Pedrazzoli, J., Jr.; Gambero, A. Attenuation of colitis injury in rats using Garcinia cambogia extract. Phytother. Res. 2009, 23, 324-329.

67. Jiang Y.; Hu, W.; Han, W.; Yeo, J.-H.; Wang. M.-H. Antioxidant and nitric oxide production inhibitory activities of scouring rush (Equisetu hyemale L.). Food Sci. Biotechnol. 2012, 21, 1037-1044.

68. Tae, K.-S.; Kim, S.-J. Inhibition of iNOS and DNA oxidation by methanol extract of Schizonepeta tenuifolia. Trop. J. Pharm. Res. 2012, 11, 397-404.

69. Shen, C.C.; Lin, C.-F.; Huang, Y.-L.; Wan, S.-T.; Chen, C.-C.; Sheu, S.-J.; Lin, Y.-C.; Chen, C.-C. Bioactive Components from the Mycelium of Antrodia salmonea. J. Chin. Chem. Soc. 2008, 55, 854-857. 
70. Huang, G.J.; Pan, C.H.; Liu, F.C.; Wu, T.S.; Wu, C.H. Anti-inflammatory effects of ethanolic extract of Antrodia salmonea in the lipopolysaccharide-stimulated RAW246.7 macrophages and the $\lambda$-carrageenan-induced paw edema model. Food Chem. Toxicol. 2012, 50, 1485-1493.

71. Rosillo, M.A.; Sánchez-Hidalgo, M.; Cárdeno, A.; Aparicio-Soto, M.; Sánchez-Fidalgo, S.; Villegas, I.; de la Lastra, C.A. Dietary supplementation of an ellagic acid-enriched pomegranate extract attenuates chronic colonic inflammation in rats. Pharmacol Res. 2012, 66, 235-242.

72. Jagtap, A.G.; Niphadkar, P.V.; Phadke, A.S. Protective effect of aqueous extract of Bombax malabaricum DC on experimental models of inflammatory bowel disease in rats and mice. Indian J. Exp. Biol. 2011, 49, 343-351.

73. Jung, M.; Triebel, S.; Anke, T.; Richling, E.; Erkel, G. Influence of apple polyphenols on inflammatory gene expression. Mol. Nutr. Food Res. 2009, 53, 263-280.

74. Dost, T.; Ozkayran, H.; Gokalp, F.; Yenisey, C.; Birincioglu, M. The effect of Hypericum perforatum (St. John's Wort) on experimental colitis in rat. Dig. Dis. Sci. 2009, 54, 1214-1221.

75. Triebel, S.; Trieu, H.L.; Richling, E. Modulation of inflammatory gene expression by a bilberry (Vaccinium myrtillus L.) extract and single anthocyanins considering their limited stability under cell culture conditions. J. Agric. Food Chem. 2012, 60, 8902-8910.

76. Edmunds, S.J.; Roy, N.C.; Love, D.R.; Laing, W.A. Kiwifruit extracts inhibit cytokine production by lipopolysaccharide-activated macrophages, and intestinal epithelial cells isolated from IL10 gene deficient mice. Cell Immunol. 2011, 270, 70-79.

77. Zia-Ul-Haq, M.; Landa, P.; Kutil, Z.; Qayum, M.; Ahmad, S. Evaluation of anti-inflammatory activity of selected legumes from Pakistan: in vitro inhibition of cyclooxygenase-2. Pak. J. Pharm Sci. 2013, 26, 185-187.

78. Mueller, M.; Hobiger, S.; Jungbauer, A. Anti-inflammatory activity of extracts from fruits, herbs and spices. Food Chem. 2010, 122, 987-996.

79. Jedinak, A.; Dudhgaonkar, S.; Wu, Q.-L.; Simon, J.; Sliva, D. Anti-inflammatory activity of edible oyster mushroom is mediated through the inhibition of NF-kB and AP-1 signaling. Nutr. J. 2011, 16, 10-52.

80. Chiang, S.S.; Wang, L.T.; Chen, S.Y.; Mau, J.L. Antibacterial and Anti-Inflammatory Activities of Mycelia of a Medicinal Mushroom from Taiwan, Taiwanofungus salmoneus (Higher Basidiomycetes). Int. J. Med. Mushrooms. 2013, 15, 39-47.

81. Ruangnoo, S.; Jaiaree, N.; Makchuchit, S.; Panthong, S.; Thongdeeying, P.; Itharat, A. An in vitro inhibitory effect on RAW 264.7 cells by anti-inflammatory compounds from Smilax corbularia Kunth. Asian Pac. J. Allergy Immunol. 2012, 30, 268-274.

82. Karimi, E.; Jaafar, H.Z.; Ahmad, S. Antifungal, Anti-inflammatory and cytotoxicity activities of three varieties of labisia pumila benth: from microwave obtained extracts. BMC Complement Altern. Med. 2013, doi:10.1186/1472-6882-13-20.

83. Khlifi, D.; Sghaier, R.M.; Amouri, S.; Laouini, D.; Hamdi, M.; Bouajila, J. Composition and anti-oxidant, anti-cancer and anti-inflammatory activities of Artemisia herba-alba, Ruta chalpensis L. and Peganum harmala L. Food Chem. Toxicol. 2013, 55, 202-208. 
84. Jiménez-Estrada, M.; Velázquez-Contreras, C.; Garibay-Escobar, A.; Sierras-Canchola, D.; Lapizco-Vázquez, R.; Ortiz-Sandoval, C.; Burgos-Hernández, A.; Robles-Zepeda, R.E. In vitro antioxidant and antiproliferative activities of plants of the ethnopharmacopeia from northwest of Mexico. BMC Complement. Altern. Med. 2013, doi:10.1186/1472-6882-13-12.

85. Han, S.; Lee, J.H.; Kim, C.; Nam, D.; Chung, W.S.; Lee, S.G.; Ahn, K.S.; Cho, S.K.; Cho, M.; Ahn, K.S. Capillarisin inhibits iNOS, COX-2 expression, and proinflammatory cytokines in LPS-induced RAW 264.7 macrophages via the suppression of ERK, JNK, and NF- $\kappa$ B activation. Immunopharmacol. Immunotoxicol. 2013, 35, 34-42.

86. Choe, K.I.; Kwon, J.H.; Park, K.H.; Oh, M.H.; Kim, M.H.; Kim, H.H.; Cho, S.H.; Chung, E.K, Ha, S.Y.; Lee, M.W. The antioxidant and anti-inflammatory effects of phenolic compounds isolated from the root of Rhodiola sachalinensis A. BOR. Molecules 2012, 17, 11484-11494.

87. Bang, S.Y.; Kim, J.H.; Kim, H.Y.; Lee, Y.J.; Park, S.Y.; Lee, S.J.; Kim,Y. Achyranthes japonica exhibits anti-inflammatory effect via NF- $\mathrm{BB}$ suppression and HO-1 induction in macrophages. J. Ethnopharmacol. 2012, 144, 109-117.

88. Chae, H.S.; Kang, O.H.; Keum, J.H.; Kim. S.B.; Mun, S.H.; Seo, Y.S.; Kim, M.R.; Choi, J.G.; Shin, D.W.; Oh, Y.C.; et al. Anti-inflammatory effects of Hylomecon hylomeconoides in RAW 264.7 cells. Eur. Rev. Med. Pharmacol. Sci. 2012, 3, 121-125.

89. Debnath, T.; Jin, H.L.; Hasnat, M.D.; Kim, Y. Samad, N.B.; Park P.-J.; Lim, B.O. Antioxidant potential and oxidative DNA damage preventive activity of Chrysanthemum indicum. J. Food Biochem. 2011, doi:10.1111/j.1745-4514.2011.00644.x.

(C) 2013 by the authors; licensee MDPI, Basel, Switzerland. This article is an open access article distributed under the terms and conditions of the Creative Commons Attribution license (http://creativecommons.org/licenses/by/3.0/). 